\title{
The Role of Village Agency (BPD) in Development Planning; Study in the Dirung Lingkin Village
}

Benz Roy ${ }^{*}$, Asmu'i, Jamal Uddin

Master Program of Government Science, Lambung Mangkurat University, Banjarmasin, Indonesia

DOI: 1 10.36348/sjef.2020.v04i06.008 $\quad$ | Received: 30.05.2020 | Accepted: 08.06.2020 | Published: 12.06 .2020

*Corresponding author: Benz Roy

\section{Abstract}

The study aims to determine the function of the Village Consultative Body in Dirung Lingkin Village, Murung Raya Regency, and to find out the factors that influence the role and function of the Village Consultative Body in the implementation of development. This research lasted approximately 3 months and is located in Dirung Lingkin Village, Bulukumba Regency. This type of research is a type of descriptive research that is for exploration and clarification of a phenomenon or social reality using data collection techniques conducted using interviews, document studies, literature studies, and observations. The results showed the role and function of the BPD in development in Dirung Lingkin Village, Murung Raya Regency, namely discussing and agreeing on a village regulation draft with the village head, accommodate and channel the aspirations of the community, as well as supervise the performance of village heads, related to the function of BPD regarding supervision. Besides, factors that influence the function of the Village Consultative Body in the implementation of development consist of supporting factors namely the level of BPD education in the recruitment or selection system of BPD members, the community, the pattern of cooperative relations with the village government, as well as the socio-cultural factors while the inhibiting factor is the participation of members of the meeting. Still lacking and facilities or the Secretariat of the BPD that does not yet exist for an office in Dirung Lingkin Village.

Keywords: Role, Village Consultative Body, Planning, Development.

Copyright @ 2020: This is an open-access article distributed under the terms of the Creative Commons Attribution license which permits unrestricted use, distribution, and reproduction in any medium for non-commercial use (NonCommercial, or CC-BY-NC) provided the original author and source are credited.

\section{Preliminary}

The village is an area that often escapes the attention of many people, especially in the field of government, whereas if examined deeper it turns out that the village is a layer of government directly in contact with the community [1]. A saying goes that the strength of the iron chain lies in the weakest chain. In describing the national government system as a chain of government systems starting from the central, regional, and village, then the village is the weakest link [2]. Almost all aspects show how weak the position and existence of the village in the constellation of government, even though the village is the last link between the government and the community that takes it to the final goal that has been outlined as a shared ideal [3].

The village is the forerunner to the formation of political society and government in Indonesia. InLaw Number 23 the Year 2014 concerning Villages, referred to as villages and adat villages or referred to by other names hereinafter referred to as villages, are legal community units that have territorial boundaries that are authorized to regulate and administer government affairs, the interests of local communities based on community initiatives, origin, and traditional rights recognized and respected in the system of government of the Unitary Republic of Indonesia [4, 3].

Original autonomy has that the authority of the village government in determining and managing community interests is based on the origin and sociocultural values that exist in the local community, but must be implemented in a modern administrative perspective [5]. In this case, the village government must realize the rights and obligations it has to be able to regulate and manage the interests of its people based on the origin of customs that apply in the national government system under local government. This also means that the granting of authority to village governments is generally aimed at restoring original rights through recognition of the diversity that has so far been united with village nomenclature [6]. 
To exercise their authority to regulate and manage the interests of their communities, the village consultative body was formed as a legislative body (establishing government regulations on village regulations) and accommodating and channeling the aspirations of the community together with the village head $[7,8]$. This institution is essentially a village government partner that has an equal position in carrying out government affairs, development, and community empowerment. This is where the ability (capability) Members of the Village Consultative Body (BPD) is needed in carrying out its role. Village Government Affairs run well if there is good cooperation between BPD officials. Capability usually shows the potential and strength that is in a person to show the ability in the field of village governance, for those BPD members are required to have extensive insight both experience, knowledge, skills, and attitudes. One's knowledge and skills in participating directly in the administration of the Village Government have an influence on one's ability (BPD Members) in handling input from the community and in making village decisions so that decisions made are following the wishes and aspirations of the community [9].

BPD members do not understand their role and function in the village, resulting in the less optimal role and support of the BPD as an institution needed to assist the Village Government in the field of development in absorbing people's aspirations. These results in many people's aspirations that are not able to be absorbed which has an impact on the level of development that runs slowly. The main obstacle is the limited level of ability of BPD members, so they have not been able to carry out their roles to the full. This can be seen from the fact that some BPD members rarely attend meetings either in the discussion of development plans, development implementation or development results evaluation meetings, besides, it is still based on the lack of effective communication between members of the BPD and Village Officials so that development information is sometimes inaccurate, uneven knowledge and insight possessed by BPD Members so that there are differences in seeing and understanding a problem. Based on some of these descriptions shows the low role of BPD members in development so that, the main role of BPD is to protect, legislate, supervise and accommodate the aspirations of the community cannot run according to expectations. Should be in line with the duties and functions of the BPD which is very instrumental in determining the success of the implementation of the Village Government, village development and village community development, the BPD members must have an appropriate and better level of knowledge and insight, so that the success rate of development can be achieved to the maximum. This article aims to describe the role of the Village Consultative Body in Dirung Lingkin Village, Murung Raya Regency.

\section{RESEARCH METHODS}

A qualitative approach as a research procedure that produces descriptive data in the form of written or oral words from people and observable behavior. This approach is directed at the background of the individual holistically (whole) $[10,11]$. So, in this case, it is not allowed to isolate individuals or organizations into variables or hypotheses, but it is necessary to view them as part of a whole. This qualitative approach is specifically directed towards the use of case study methods. As that the qualitative approach can also be called a case study or qualitative, namely in-depth and detailed research about everything related to the research subject $[12,13]$. The case study method can be interpreted as a technique of studying an individual indepth to help him get a good adjustment [14]. The study was conducted in the Dirung Lingkin Village, Murung Raya Regency.

The collection techniques used include the following: 1) Observation (Observation) to see and explore the role of BPD in planning and building Dirung Lingkin Village, Murung Raya Regency, 2) Interview as a process of collecting data with questions and answers and face to face by researchers and respondents by using interview guides (interview guides) and in-depth interviews (in-depth interviews), 3) Documentation in the form of collecting written objects such as books, scientific magazines, archives, personal documents and official documents of related parties [15]. The data analysis techniques used in this study are data analysis techniques from Miles and Huberman, namely: 1) Data Reduction as a selection process, focusing on simplification, abstracting,

\section{RESULTS AND DISCUSSION}

The presence of the Village Consultative Body (BPD) in the Village Government with its various functions and authorities is expected to be able to realize a check and balance system in the village administration. This is intended as an embodiment of democracy, in the administration of village government, the Village Head and the BPD work together in managing and regulating the interests of the local community based on recognized and respected local origins and customs. In implementing the function of the BPD as a village legislative body and community aspirations container it is expected to be achieved properly and effectively $[16,17]$. In other words, the village government and BPD can work well together in organizing the government, of course, with the support of the community. Village regulations are the highest legal product issued by the governing village government, which is made by both the proposal of the village head and the BPD proposal which is mutually agreed upon and stipulated by the village head and announced in the village news which is made both as the implementation/elaboration of more legislation as well as for the administration of village government. 
The formulation of village regulations should be carried out through the following mechanisms:

1. The village regulation draft prepared by the BPD and the Village Head, submitted by the BPD leader to all BPD members no later than seven days before the draft village regulation discussed in a plenary meeting.

2. The village head's draft discussion was carried out by the BPD together with the village head.

3. The draft can be withdrawn before it is discussed together by the BPD and the village head.

4. The village regulation draft that has been agreed with the BPD and the village head is submitted by the BPD leader to the village for set become a village regulation no later than seven days from the date of joint determination.

5. The draft village regulation must not conflict with the public interest and higher laws and regulations.

6. Village regulations apply after promulgation in village news. In making village regulations, it is first seen from what are the aspirations of the community and what is needed in Dirung Lingkin. Then from the community's aspirations that were conveyed backs pressed together by BPD in BPD internal meetings whether aspirations Public it is necessary or not then conveyed in a meeting with the village head.

The mechanism in establishing village regulations is several stages or steps taken by the BPD in establishing Village Regulations that accommodate proposals both from the BPD and the Village Head where these proposals can be the basis or benchmark in running the Village Government [18, 19]. After that, the proposal is discussed and evaluated, and the results of the evaluation are then jointly determined in the form of a draft and then formulated in the form of a Village Regulation. In the stage of forming Village Regulations, ideas or proposals originated more from the Village Head than from the BPD. This is because BPD's knowledge and insight are still minimal and also because the elected village head knows more about the condition and condition of the village. The process of making Village Regulations starts from formulating village regulations to the stage of establishing Village Regulations which are carried out jointly with the village government, no significant obstacles or obstacles are encountered.

BPD conducts discussions and agrees to the draft regulations and their activities in the discussion have proven that the implementation of BPD functions is already very well run. So that in 2018 there were two village regulations made by the BPD along with the village head: Dirung Lingkin Village Regulation Number 03 of 2018 regarding the lease of village assets and village regulations on the APBDesa and stipulated and announced by the BPD and the Village Head on May 11, 2018. Although There Perdes are made by BPD together with the village head it is necessary to increase the understanding of all BPD members in making Perdes through training on how to make Perdes.

Dirung Lingkin Village Community is a community that has a complexity of needs. In line with this, they need quality services from the local village government who must always try to improve their ability to provide better services according to the guidance of the community. One of the main tasks and functions of the Village Consultative Body is to accommodate and channel the aspirations of the community. The Village Consultative Body (BPD) as the people's representative in the village is a place for the village community to express their aspirations and to accommodate all complaints and then follow up on these aspirations to be conveyed to the relevant agencies or institutions. This requires knowledge by the community about the existence and role of the BPD. After a village regulation is established,

Conceptually, the link between the village head and the Village Consultative Body (BPD) is more on checks and balances which is essentially a mechanism of mutual control between village institutions to avoid deviations of power in the context of community welfare. In the perspective of the distribution of power BPD is a village legislative body that functions as a village regulation maker, a forum for community aspirations and also oversees the implementation of village regulations in the context of strengthening the implementation of the performance of the Village Government while the Village Head is an Executive Board that functions as implementing village regulations.

The implementation of the village government can move the community to participate in the development and administration of village administration, so any decision taken must be based on deliberation to reach consensus. BPD is a forum for the aspirations of rural communities. The aspiration container can be interpreted as a place where the wishes or aspirations of the community are conveyed, accommodated, and then distributed. Based on the authors' observations and research, the duties and authority of the BPD in exploring, accommodating, and distributing the aspirations of the people have been carried out under the duties and authorities of the regional regulations. Some examples of complaints submitted by the community to the Salassae village BPD, especially in the field of development, namely:

1. Irrigation Problems

2. Rehabilitation of market buildings

3. Village Office Renovation

4. Improvement of posyandu buildings

5. Development of Tani road access

\section{Care Starling is Broken}

After the village people's aspirations are accommodated, the next step is for the BPD to channel 
the aspirations of the community in a meeting organized by the BPD. After obtaining aspirations and then discussing them, BPD then continues and delivers as intended by the community. However, on this occasion, the village government was still allowed to explain the aspirations expressed by the community. This illustrates that the village head and the Village Consultative Body have been trusted and supported by residents.

BPD as the people's representative in the village is a place for the community to accommodate all of their complaints and then follow up on these aspirations to be conveyed to the relevant agencies or institutions. Many ways were taken to accommodate all complaints which were then followed up by written and oral means. Written way, for example, these problems are related to village development and progress and are further discussed and discussed in the form of village regulations, and verbally, namely, the community expresses their aspirations directly to the BPD when there is a village meeting or village meeting and when there is a BPD meeting.

The Village Head in implementing the village government is also entitled to make the Village Head's decision. The decision of the village head is made to facilitate the implementation of village regulations. From the data obtained from the Village Head's office, several decisions have been issued by the Village Head, including the decision of the Village Head regarding the Compilation of the Village Head's Annual Work Program which is used as a guideline for the Village Finance Revenue and Expenditure Budget Plan (RAPBDes). The supervision carried out by the Village Consultative Body on the decision of the Village Head is as follows:

1. Look at the decision making process and the contents of the decision.

2. See whether the contents of the decision are appropriate to be used as guidelines for the preparation of the RAPBDes.

3. Monitor whether the decision is carried out or not.

4. Oversee whether in carrying out the decision there is a fraud.

5. Follow up if there is any misappropriation in implementing the decision.

In implementing village regulations, BPD carries out control or supervision of village regulations and Village Head Regulations. The implementation of the supervision of Village Regulations and Village Head Regulations referred to herein is the implementation of supervision of APBDes and RPJMDes which are used as village regulations and also oversight of Village Head decisions. The supervision carried out by the BPD of Dirung Lingkin Village, Bulukumpa Subdistrict, Murung Raya Regency is to supervise the Implementation of Village Regulations and supervise the Village Budget.
In realizing an effective organization in the implementation of its functions cannot be separated from various factors that affect its performance in achieving goals. As with BPD, to be effective does not necessarily just happen but several factors influence it. Based on the data obtained in the field, several factors influence the effectiveness of BPD function implementation, namely supporting and inhibiting factors.

1. Supporting factors

a. The level of education of BPD members of 5 people, 3 of whom are strata 1 , while the other 2 people graduated from high school. The level of education of BPD members is very supportive in carrying out the roles and functions of BPD so that the recruitment and selection system of BPD members uses a direct election system by community representatives in each hamlet. This has led to a high level of community trust in people who are BPD members. Because the people chosen are community choices that are known and can be measured the capabilities and capabilities owned and by direct election by the community can be ascertained that there is no nepotism by the relevant government. The recruitment/election system of BPD members in Dirung Lingkin Village uses a direct election system by community leaders who are trusted by the local community. The people chosen for this BPD position are people whois considered able both in terms of education, and its influence in society, in this case, able to work together and be able to capture and read the problems that exist in the village.

b. Society is a determining factor for the success of the BPD in carrying out its functions, the amount of support and appreciation from the community to the BPD makes the BPD have more room to be able to carry out its functions. Support from the community not only on the many aspirations that come also from the implementation of a Perdes. It is the will and enthusiasm of the community that makes all decisions of the BPD and the Village Government easy to implement. Public participation both in the form of aspirations and in the implementation of a decision largely determines the function of the BPD.

c. The social culture that is related to the lifestyle of the community of Dirung Lingkin Village which is still very thick with a culture of mutual respect has a positive influence on the effectiveness of the implementation of the BPD function. The community of Dirung Lingkin Village still highly upholds the culture of respecting older people and respecting younger people so that a sense of kinship takes precedence between them. The BPD and the village government always make this a 
foundation to minimize if there are differences between communities that can lead to potential conflicts.

d. The pattern of cooperative relations between the BPD and the Village Government so that the effectiveness of the duties and functions of the BPD emerge is the creation of a harmonious relationship between the BPD and the Village Government by always respecting and respecting each other, there it is good intentions to help one another and remind one another. This harmony in the village is caused by the existence of common goals and interests to be achieved, namely to prosper the village community. As an element of partnership in the administration of village governance, the BPD and the Village Government are always aware of an equal position between the two.

2. Obstacle factor

a. Participation of BPD members in meetings that are still lacking. BPD has an important role in establishing policies in organizing the Village Government. BPD is a container of aspiration and a container of the planning, implementation, and control of community activities and other bodies in village development. To carry out the functions of the BPD above, it requires people who can communicate well and can analyze the aspirations or what is desired by the community which is then coordinated with the Village Government. Stratification or education level can also influence the successful implementation of BPD functions. With the high degree of knowledge, a person has, the higher the level of analysis of social phenomena that occur within a society. However, the reality is that the level of education in BPD management is still standard, so this is an inhibiting factor in formulating village regulations.

b. Means for carrying out tasks. BPD is very much needed as a secretariat container that is used in carrying out all activities relating to BPD activities starting planning and administration. Containers or places in the form of offices are needed by BPD for the organization of all BPD activities. This is also intended to facilitate lines of communication and coordination between other BPD members. The fact on the ground is that the BPD secretariat is needed because the secretariat is currently an obstacle in the implementation of the roles and functions of the BPD so there is no place for BPD members to work so that the role of the BPD is even more effective.

\section{CONCLUSION}

The role of the BPD in development in the Dirung Lingkin Village Murung Raya Regency is 1) discussing and agreeing on a village regulation draft with the village head where coordination is always carried out by the village government, in this case, the village head with the BPD in the process of discussing and drafting village regulations. So that in 2018 there will be two Perdes made by BPD together with the Village Head namely Perdes for Leasing assets and APBDes Perdes; 2) accommodate and channel the aspirations of the community, the role of BPD in this case as a reservoir of community aspirations has been carried out properly as expected. This can be seen from the fact that BPD has often become a forum for the community to express their aspirations about village development. And the involvement of BPD in development without having to wait for complaints from the public. When there are community aspirations that are needed by Dirung Lingkin Village, the BPD immediately conducts an internal meeting with other BPD members and whether the community's aspirations are accepted or acted upon. After that the BPD presented the results of its internal meeting to the village government, in this case, the village head about what was input from the community of Dirung Lingkin Village; 3) supervise the performance of the village head, related to the function of BPD regarding supervision can be said to have run optimally by seeing that there are no obstacles faced by BPD in the supervision process carried out. In practice, there are supporting and inhibiting factors. Supporting factors for BPD in the implementation of development include; 1) the quality of education of BPD members in recruitment uses a direct election system by the community. This makes high public trust in people who are members of the BPD, 2) Great support from the community towards BPD, 3) Socio-cultural conditions where the lifestyle of Dirung Lingkin villagers is very thick with a culture of mutual respect, 4) the pattern of cooperative relations with the government village, which is harmonious between the BPD and the Village Government. While the inhibiting factors include; 1) Participation of members of the meeting is still lacking, 2) BPD does not have a secretariat to support planning and administration activities.

\section{REFFERENCE}

1. Bintarto. (1989). Interaksi Desa Kota dan Permasalahannya. Jakarta: Ghalia Indonesia.

2. Agussalim, A. G. (2007). Pemerintahan Daerah (Kajian Politik dan Hukum). Bogor: Ghalia.

3. Abdul, C. D. (2015). Pelayanan Publik Tingkat Desa. Yogyakarta: INTERPENA.

4. Utami, E. T. (2007). Peranan Badan Permusyawaratan Desa dalam Perencanaan Pembangunan Desa. Medan: Universitas Sumatera Utara.

5. Widjaja, H. (2003). Otonomi Desa. Jakarta: PT Raja Grafindo Persada.

6. Nurcholis, H. (2011). Pertumbuhan dan Penyelenggaraan Pemerintahan Desa. Jakarta: Penerbit Erlangga. 
7. Santoso, P. (2003). Pembaharuan Desa Secara Partisipatif. Yogyakarta: Pustaka Pelajar.

8. Ali, F., \& Baharuddin. (2013). Pengantar Ilmu Administrasi. Gorontalo: Penerbit PT BIFAD Press.

9. Karim, A. G. (2003). Kompleksitas Persoalan Otonomi Daerah di Indonesia. Yogyakarta: Pustaka Pelajar.

10. Afifuddin, B. A. S., \& Saebani, B. A. (2009). Metodologi penelitian kualitatif. Bandung: Pustaka Setia.

11. Gunawan, I. (2014). Metode Penelitian Kualitatif Teori dan Praktik. Jakarta: Bumi Aksara.

12. Cresswell, J. W. (2010). Research Design Pendekatan Kualitatif, Kuantitatif, dan. Mixed. Yogyakarta: Pustaka Pelajar.

13. Sarman, M. (2004). Panduan Prosedur Penelitian dan Penulisan Tesis, . Banjarbaru. Kalsel: Program MSAP UNLAM.
14. Iskandar. (2008). Metodologi Penelitian Pendidikan dan Sosial (Kuantitatif dan. Kualitatif). Jakarta: GP Press.

15. Sarman, M. (2004). Pengantar Metodologi Penelitian Sosial. Banjarmasin. Kalsel: Pustaka FISIP UNLAM.

16. Syarifin, P. J., \& Dedah. (2005). Hukum Pemerintah Daerah. Bandung: Pustaka Bani Quraisy.

17. Siagian, P. S. (2008). Pengantar Manajemen. Jakarta: Bumi Aksara.

18. Syarifuddin, A. (1976). Pengaturan Koordinasi Pemerintah Daerah. Bandung: Tarsito.

19. Siagian, S. P. (2003). Administrasi Pembangunan. Jakarta: PT. Gunung Agung.

20. Nasution. (2009). Metode Research (Penelitian Ilmiah). Jakarta: Bumi Aksara.

21. Sugiyono. (2016). Memahami Penelitian Kualitatif. Bandung: Alfabeta. 